\title{
Funding Challenges of Small and Medium Enterprises in Transition Countries: Kosovo Case Study
}

\author{
Fahredin Berisha ${ }^{1}$ \\ ${ }^{1}$ FAMA Coledge, Prishtina, Kosovo \\ Correspondence: Fahredin Berisha, Professor Assistant at FAMA Coledge, Prishtina, Kosovo. Tel: 383-4429-4282. \\ E-mail: fahredin.berisha@gmail.com
}

Received: May 31, 2020; Accepted: June 18, 2020; Published: June 20, 2020

\begin{abstract}
SMEs play a very important role in the development of economies of different countries and they are now considered as a key factor of economic development. They affect unemployment, promote social welfare and can be treated as a promoter of economic growth. The paper addresses the role and importance of financing SMEs in transition countries including Kosovo. The study examines the key factors affecting the increase of SME financing from external sources, namely bank lending since other external sources of financing in Kosovo are scarce and almost non-existent. For the purposes of this paper, data from 215 SMEs surveyed in Kosovo were used, randomly distributed across manufacturing, services and commerce sectors. Data collection was done in the period JanuaryApril 2016, and their processing was carried out with SPSS (Social Package for Social Science). In order to have more consistent information during data processing, certain models were used in the paper: Paried-Samples T Test, which was used to investigate the difference between two sets of averages, which indicates that the business plan for the enterprise is relevant to bank loan access. The One Way Anova model was used to test the differences between two or more averages, and through this model is proved that high-profit enterprises have achieved easier access to bank loans. Also following the One Way Anova and Post Hoc LSD test, there were found differences between groups of enterprise by their types, activity and age. The research shows that enterprises with older ages have been able to obtain more easily bank loans. The One Way Anova and Welch-Brown-Forthyse test was used to deal with the level of education of business owners, whereby it was found that owners with a high level of education had easier access to bank loans. Through the Indepedent Samples T Test technique it was found that there is a significant difference between the age groups of the owners based on the mean and standard deviation.
\end{abstract}

Keywords: SMEs, finance, bank, loans, transition, countries, Kosovo

\section{Introduction}

SMEs play an important role in economic development, both in developed countries and in developing ones. One of the main challenges they face are financial assets, which are increasingly absent. However, they also face many problems during the establishment and advancement of their business. Initially, intial capital is extremely low, so obtaining external funding is extremely difficult due to a number of factors: inexperience in the market, lack of management skills, insufficient funds, low collateral which require financial intermediaries as collateral for loan coverage, etc.The focus of this research is to provide financial support from external funding sources, specifically from the bank loan. Funding is the main determinant of growth and development of SMEs, both in developed countries and the developing ones (Ardic et al., 2011; De la Torre, et al., 2011). The literature which has addressed the issue of funding the SME through bank loans is different, especially in developed countries. However, the issue of funding SME is also addressed in transition countries, including Kosovo. Various authors have examined the difficulties and challenges they are facing SMEs in obtaining external sources of their funding, namely bank loans (Vo, 2017, Harvie, et al., 2013; Tmava et al., 2013; Beck et al. 2006). Recent studies related to SME financing are closely linked to economic growth and development. Thus, according to Ayyagari et al. (2007), SMEs in countries with high-incomes contribute an average of 50 percent of gross domestic product. While Beck et al. (2008b) by examining the role and importance of SMEs in the OECD countries, have found that SMEs with less than 250 employees employ two-thirds of the official labor force. Therefore, their role and importance in development is undisputed. Also Hallberg (2001), finds that SMEs represent growing sector in poor countries around the world and thus form the basis for development in general. Moreover, SMEs in developing countries have difficulties in accessing bank loans due to the high risk of failing loans, low profitability and lack of collateral required by banks (Harvie, et al., 2013,). The various difficulties of SMEs with limited access to finance, mainly 
bank loans, are encountered by many other authors (Carbo-Valverde, Rodriguez-Fernandez, \& Udell, 2016; CarboValverde, S., Rodriguez-Fernandez, F., \& Udell, G. F. 2016). Also, Brinckmann et al. (2011) find that small firms have greater difficulties accessing finance, compared to large firms. Access to finance and capital, for most of the SMEs in the region, including Kosovo, seems to be even more difficult. This is due to the weakness of the banking institutions, lack of capital market but also lack of inefficient legal framework regarding credit and collateral valuation. SME financing and access to finance play a crucial role in the growth process and development of enterprise (WB, 2011). Moreover, it is known that Kosovo SMEs have major problems with collateral, such as loan repayment guarantee, warranty, short term bank loans etc. This paper examines the various factors that influence the issue of SME financing through bank credit: collateral, business experience, type of activity, owner's gender, age, place of business, etc. Despite the importance of SMEs for creating new jobs and reducing unemployment, part of the great literature which deals with the financing of SMEs, shows that SMEs face greater obstacles to funding sources compared with large enterprises, which limits their growth and development. Numerous studies through the use of survey data at the SME level find that access to finance and cost of credit are not only barriers to SME funding, but also limit more SMEs in growth and development compared to big companies. Small firms find it more difficult for commercial banks to finance them, especially when it comes to long-term loans, for a variety of reasons: lack of collateral, difficulties in approving credit validity, low cash flow, unstable credit history, high-risk premiums, and underdeveloped borrower relationships (Nyugen, 2017, Galindo dhe Schiantarelli, 2003; Beck et al. 2006; and Beck and Demirgüç-Kunt, 2006). However, according to Ayyagari, Demirgüç-Kunt and Maksimovic, 2006, through cross-country evidence treatment, SMEs are more limited in their functioning and growth in relation to large enterprises and access to financial services. According to Ayyagari, Demirgüç-Kunt and Maksimovic (2006), access to finance and the cost of financing are often listed as one of the main difficulties in the business environment of SMEs. Specifically, in the sample treated in 71 different countries, mainly developing countries, the cost of financing was estimated as a major barrier to growth by over $35 \%$ of the treated SMEs. This is more important than any other characteristic in the business environment, including taxation and macroeconomic instability. According to Ayyagari, Demirgüç-Kunt and Maksimovic (2006), funding is one of the few characteristics of the business environment that along with crime and political instability are strongly associated with firm growth, while other features have at least an indirect effect on the growth of the firm. Whereas, according to Beck, Demirgüç-Kunt, Laeven and Maksimovic (2006) find that small firms consistently report higher funding barriers than medium and large ones. Even in Kosovo, the issue of SME financing is a challenge in itself, as they face difficulties in securing the collateral needed as a necessity by commercial banks, inferior managerial experience, and inadequate financial statements that make access to finance from external sources difficult, which is also evident in the following analysis.

\section{Nature and Definition of SMEs}

Currently, in the professional and scientific literature SMEs are extensively treated, but still lacks a common definition which would be acceptable to all countries. One of the main challenges when analyzing the various factors that influence the growth and development of SMEs is the lack of a universal definition of SMEs that is acceptable to all countries. The definition criteria for SMEs vary depending on the country. This is because the criteria for their definition are not standard for all countries. According to the World Bank study, there are over 60 definitions of SMEs used in 75 different countries around the world. According to the World Bank (Small Business Act, USA, 1953), SMEs are defined as businesses that are independently owned and operated in its field and activity. There are relevant definitions for SMEs, one of them given by the authors (Stanworth \& Gray 1991), defining them as "a small market shareholder, one that is managed by the owner himself and is fully independent in decision-making, beyond any control of external". It should be noted that even in the US for SMEs, there is no universal definition despite the fact that many quantitative and qualitative determinations have been made. However, the guiding criteria are: total wealth, ownership status, annual turnover, number of employees always based on the industry average. Among the definition which is most applicable is the definition of SMEs in the European Union. Thus, according to EU recommendation 2003/361, the main factors underlying SMEs are: Number of staff (staff headcount) and annual turnover (either turnover or balance sheet total).

Table 1. SMEs definition by UE

\begin{tabular}{|c|c|c|c|}
\hline Company category & Staff headcount & Turnover & Balance sheet total \\
\hline Medium-sized & $<250$ & $\leq € 50 \mathrm{~m}$ & $\leq € 43 \mathrm{~m}$ \\
\hline Small & $<50$ & $\leq € 10 \mathrm{~m}$ & $\leq € 10 \mathrm{~m}$ \\
\hline Micro & $<10$ & $\leq € 2 \mathrm{~m}$ & $\leq € 2 \mathrm{~m}$ \\
\hline
\end{tabular}

Source: Commission Recommendation of 6 May 2003. 
In Kosovo, the definition of SMEs is defined by the Law 2005-02-L5 on SME Support, which fits the definition of SMEs by EU, based only on the first criterion, namely the number of employees.

\section{SME in Kosovo}

The role and importance of SME for Kosovo's economy is indisputable. Kosovo, as a small war-torn country, was created as a state recently with the collapse of ex YU, inherited a completely devastated economy, but also is facing many problems of ownership transformation. Currently, according to KBRA (2016) the profile of businesses in Kosovo is dominated by SMEs, with over $99 \%$. Of these, $98.4 \%$ is micro enterprises, $1.35 \%$ is small enterprises, $0.22 \%$ is medium enterprises and only $0.06 \%$ is large enterprises. The total number of registered companies in Kosovo is 149,843; however, according to the tax administration of Kosovo, the number of active enterprises is only 66,986. It means that more than half of them are inactive, which is an important indicator of the difficulty of accessing finance. Kosovo's SMEs are estimated to contribute $43.3 \%$ to the country's GDP (SDSMVK, 2011).

\section{Research Objective}

SMEs are the backbone of economic development, therefore the purpose of this study is to empirically investigate the role and importance of external sources of SME financing in Kosovo, through the investigation of different factors such as: capital resources structure, sector of activity, turnover, life expectancy, number of employees, education, age, gender, business plan. The specific task in our research is to determine some features of SMEs, as follows:

- What is the role of the business plan in getting a bank loan to SMEs?

- How determinant is the positive balance of SMEs in obtaining bank credit?

- What is the difference between SME activities in their access to bank loans?

- What is the difference between the ages of SMEs in their access to bank loans?

- What is the difference between the levels of education of SME founders in their access to bank loans?

The basic aim of this paper is to provide answers to the challenges faced by SMEs in financing their activities by using bank loans.

\subsection{Research Hypotheses}

In order to assess the factors that influence the probability of obtaining bank loans to SME's, hypotheses are set as follows:

H1: In obtaining bank loan there is significant difference between SMEs which have developed business plan and those who do not own a business plan.

$\mathrm{H} 2$ : There is a significant difference between SMEs with different profits in obtaining bank credit.

H3: There is a significant difference between commercial, service and manufacturing SMEs in obtaining bank loans.

H4: There is a significant difference between the ages of SMEs in obtaining bank loans, the older the age of SMEs the higher the probability of accessing credit.

H5: There is a significant difference between the educational levels of SME founders, in obtaining bank loan; SME founders with higher educational level have easier access to bank loan.

\subsection{Methodology}

The method used in this research is survey conducted by SMEs in the Republic of Kosovo. The survey instrument is a four-part questionnaire. Data processing was done using SPSS program. Parametric and non-parametric tests were used for hypothesis testing. The techniques used in this research for testing hypotheses are:

- Paired-Samples T Test,

- One Way Anova, Post Hock Test LSD,

- Welch- Brown-Forsythe test,

- Independent-Samples T-Test.

\subsection{Measuring Techniques}

Empirical research is based on an interview conducted with the owner, business manager or senior officials of the company. The questionnaire was organized and implemented by over 215 respondents throughout the Kosovo 
region. The time period for conducting the survey covered the first six months of 2016. Of all respondents, 148 were owners, 56 were enterprise managers and 11 were senior enterprise officials.

\subsection{Population and Sample}

Currently in Kosovo by MTI and KBRA number of SMEs registered in Kosovo includes approximately 150,000 SMEs. While active businesses registered in the tax administration of Kosovo are 66,986 businesses. The figure shows that it is impossible to test the whole population, so our research is based on the selected samples. The sample treated in research involving 215 SMEs, mostly simple and random samples, which have enabled the generation of sustainable results. The basis sample selection was obtained from MTI and KBRA.

\subsection{Research Methodology and Testing of Hypotheses}

The method used in this research is the survey conducted with SME businesses.

The sample treated in the research includes a total of 215 SMEs, and is mainly a simple and random sample. The MTI and ABRK register was used as a basis for sample selection. The survey consists of four sections which include 57 questions. The first part of the survey includes the personal data of the respondent (interviewers). The second part of the survey includes data on the profile of enterprises and their characteristics. The third part of the survey includes data on SME business barriers. The fourth part of the survey includes data on the experiences of enterprises regarding bank loans and other forms of financing. Data processing was done using SPSS program. Parametric and non-parametric tests were used for hypothesis testing. The techniques used in this research for testing hypotheses are:

- Paired-Samples T Test,

- One Way Anova, Post Hock Test LSD,

- Welch- Brown-Forsythe Test,

- Independent-Samples T-Test.

H1.There is a significant difference in obtaining bank loans between SMEs that have a business plan and those without a business plan.

For the purpose of testing the first hypothesis Paired-Samples T Test was used, this test is used to investigate the difference between the two groups of averages. T-Test determines whether the mean of one group is significantly different from the average of the other group.

Table 2. Paired-Samples T Test Results

\begin{tabular}{lrrrrrrr}
\hline & Mean & $\mathrm{N}$ & Std. Deviation & Std. Error Mean & $\mathrm{t}$ & Correlation & Sig. (2-tailed) \\
\hline Business Plan & .05 & 215 & .221 & .015 & -6.376 & .051 & .000 \\
Loan amount & 37537.674 & 215 & 86331.7359 & 5887.7755 & & .000 \\
\hline
\end{tabular}

According to the results of the analysis, the average amount of credit allowed for 215 businesses is $€ 37,538$. The Sig (2-tailed) value in the $95 \%$ confidence interval is less than $0.05 \mathrm{P}=0.000$. There is a significant difference between the averages of the SME-s with business plans and those without business plans in obtaining bank loans. In this case, the $\mathrm{H} 1$ hypothesis will be accepted (there is a difference between averages). The correlation between credit allowed and business plan is .051. In this case, it can be argued that there is a relation between bank lending and having a business plan, so businesses with a well-crafted plan are likely to have a higher chance of obtaining a bank loan.

H2. There is a significant difference in obtaining bank loans between SMEs with different net profits.

In order to test the second hypothesis One Way Anova is used, analysis of variance is used to test hypotheses about whether there is a difference between two or more averages.

Table 3. One Way Anova Results

\begin{tabular}{lrrrrr}
\hline Loan amount & & & & \\
\hline & Sum of Squares & $\mathrm{df}$ & Mean Square & $\mathrm{F}$ & Sig. \\
Between Groups & 1166775864581.260 & 96 & 12153915256.055 & & \\
Within Groups & 428202220255.952 & 119 & 3628832375.050 & 3.349 & .000 \\
Total & 1594978084837.210 & 215 & & & \\
\hline
\end{tabular}


In this case, the One Way ANOVA technique has tested the difference between averages based on their earnings on bank loan acquisition. The value of $\mathrm{F}$ is large, $\mathrm{F}=3.349$, a value which indicates that this analysis is with great importance. The table above shows that the value of $\mathrm{P}$ (Sig.) is less than $0.05 . \mathrm{P}<0.05$, where in our case it is $\mathrm{P}$ $=.000$. Therefore we can say that there is a difference between businesses according to their profits in accessing bank loans. From the graph we can see that the businesses with the highest net profits have benefited from higher loan amounts from banks in Kosovo. Therefore the $\mathrm{H} 2$ hypothesis will be accepted.

H3. There is a significant difference between commercial, servicing and manufacturing SMEs regarding obtaining bank loans

In order to test the third hypothesis One Way Anova and Post Hock LSD Tests are used. Analysis of variance is used to test the relationships and differences between the type of SMEs and their access to bank credit.

Table 4. Description of results from the average SME-s

\begin{tabular}{|c|c|c|c|c|c|c|}
\hline & \multirow{2}{*}{$\mathrm{N}$} & \multirow{2}{*}{ Mean } & \multirow{2}{*}{$\begin{array}{r}\text { Std. } \\
\text { Deviation }\end{array}$} & \multirow{2}{*}{ Std. Error } & \multicolumn{2}{|c|}{$\begin{array}{r}95 \% \text { Confidence Interval for } \\
\text { Mean }\end{array}$} \\
\hline & & & & & $\begin{array}{l}\text { Lower } \\
\text { Bound }\end{array}$ & Upper Bound \\
\hline Commercial enterprise & 114 & 22775.439 & 58229.4250 & 5453.6853 & 11970.704 & 33580.173 \\
\hline Servicing Enterprises & 89 & 51451.685 & 106361.1815 & 11274.2627 & 29046.457 & 73856.913 \\
\hline $\begin{array}{l}\text { Manufacturing } \\
\text { Enterprise }\end{array}$ & 12 & 74583.333 & 119762.2329 & 34572.3787 & -1509.959 & 150676.626 \\
\hline Total & 215 & 37537.674 & 86331.7359 & 5887.7755 & 25932.214 & 49143.135 \\
\hline
\end{tabular}

From the descriptive table we can see the averages of the three groups of SME. Commercial enterprises have an average of 22,775.44, service companies have an average of 51,451.70, and manufacturing enterprises have an average of 74,583.34. The following is One Way Anova table.

Table 5. One Way Anova Results

\begin{tabular}{lrrrrr}
\hline & Sum of Squares & df & Mean Square & F & Sig. \\
\hline Between Groups & 58542234695.281 & 3 & 29271117347.641 & \multirow{2}{*}{4.039} & .019 \\
Within Groups & 1536435850141.930 & 212 & 7247338915.764 & & \\
Total & 1594978084837.210 & 215 & & & \\
\hline
\end{tabular}

From the results of One Way ANOVAs it is seen that there is difference between the averages of the SME in terms of their access to bank credit. The value of $\mathrm{F}$ is large, in our case the value is $\mathrm{F}=4.039$, which indicates that this analysis is with great importance. The table above shows that the value of $\mathrm{P}$ (Sig.) is less than 0.05 . In this case the value of $\mathrm{P}$ is .019, so we can say that there is a difference between the types of SMEs in terms of their approach to bank loan acquisition. Therefore H3 hypothesis will be accepted. Post Hock LSD test was also performed to see the detailed differences between the groups.

Table 6. Post Hock LSD Test Results

\begin{tabular}{|c|c|c|c|c|c|c|}
\hline \multirow{2}{*}{\multicolumn{2}{|c|}{ (I) Type of SME }} & \multirow{2}{*}{$\begin{array}{r}\text { Mean } \\
\text { Difference (I- } \\
\mathrm{J} \text { ) }\end{array}$} & \multirow[b]{2}{*}{ Std. Error } & \multirow[b]{2}{*}{ Sig. } & \multicolumn{2}{|c|}{$95 \%$ Confidence Interval } \\
\hline & & & & & Lower Bound & Upper Bound \\
\hline \multirow[t]{2}{*}{$\begin{array}{l}\text { Commercial } \\
\text { enterprise }\end{array}$} & $\begin{array}{l}\text { Servicing } \\
\text { Enterprises } \\
\text { Manufacturing }\end{array}$ & $-28676.2468^{*}$ & 12041.7575 & .018 & -52413.164 & -4939.330 \\
\hline & Enterprise & $-51807.8947^{*}$ & 25836.3708 & .046 & -102736.988 & -878.801 \\
\hline \multirow[t]{2}{*}{$\begin{array}{l}\text { Servicing } \\
\text { Enterprises }\end{array}$} & $\begin{array}{l}\text { Commercial } \\
\text { enterprise } \\
\text { Manufacturing }\end{array}$ & $28676.2468^{*}$ & 12041.7575 & .018 & 4939.330 & 52413.164 \\
\hline & Enterprise & -23131.6479 & 26179.6807 & .378 & -74737.480 & 28474.184 \\
\hline
\end{tabular}




\begin{tabular}{llcrrrr}
\hline Manufacturing & $\begin{array}{l}\text { Commercial } \\
\text { enterprise }\end{array}$ & $51807.8947^{*}$ & 25836.3708 & .046 & 878.801 & 102736.988 \\
Enterprise & Servicing & & & & & \\
& Enterprises & 23131.6479 & 26179.6807 & .378 & -28474.184 & 74737.480 \\
\hline
\end{tabular}

The table above shows the results of the Post Hock LSD Test. Based on the significance level Sig. in the table for all groups it can be concluded that there is a significant difference for the groups below the 0.05 significance level. There are differences between the three groups of SMEs. According to these results it can be concluded; the difference between them is Sig level .018 and Sig. .046. From the results it can be concluded that access of commercial enterprises and service in obtaining bank loans is higher and easier than manufacturing enterprises.

H4. There is a significant difference between SMEs according to their age in obtaining bank loans, the older the SMEs are the chances for getting a loan are higher.

In order to test the fourth hypothesis One Way Anova and Post Hock LSD Tests are used. Analysis of variance was used to test the relationship and differences between the age of SMEs and their access to bank loan.

Table 7. Description of mean scores for SME

\begin{tabular}{lrrrrrr}
\hline & \multirow{2}{*}{$\mathrm{N}$} & \multirow{2}{*}{ Mean } & \multirow{2}{*}{ Std. Deviation } & \multirow{2}{*}{ Std. Error } & \multicolumn{2}{r}{ 95\% Confidence Interval for Mean } \\
\cline { 5 - 7 } & 30 & 5790.000 & 14695.4685 & 2683.0132 & Lower Bound & Upper Bound \\
\hline $0-1$ & 85 & 10968.235 & 67488.8019 & 7320.1883 & -3588.622 & 11277.378 \\
$2-5$ & 44 & 18179.545 & 34943.6928 & 5267.9599 & 7555.692 & 25525.233 \\
$6-10$ & 56 & 110083.929 & 116942.5341 & 15627.1034 & 78766.513 & 141401.344 \\
11 years and more & 215 & 37537.674 & 86331.7359 & 5887.7755 & 25932.214 & 49143.135 \\
Total & & & &
\end{tabular}

In the descriptive table we can see the averages of SME by age groups. Enterprises aged 0-1 have an average of 5,790.0, enterprises aged 2-5 have an average of 10,968.24, enterprises aged 6-10 have an average of 18,179.55, and enterprises over 11 years have an average of 110,083.93. The following is One Way Anova table.

Table 8. One Way Anova Results

\begin{tabular}{lrrrrr}
\hline & Sum of Squares & df & Mean Square & F & Sig. \\
\hline Between Groups & 401456066475.292 & 3 & 133818688825.097 & 23.657 & .000 \\
Within Groups & 1193522018361.920 & 212 & 5656502456.692 & & \\
Total & 1594978084837.210 & 215 & & \\
\hline
\end{tabular}

From the results of One Way ANOVA it is seen that there is difference between the averages of groups of SME in terms of their access to bank credit. The value of $F$ is large, in our case it is $F=23.657$, indicating that the analysis is of high importance. The table above shows that the value of P (Sig.) is less than 0.05 . Where in our case the value of $\mathrm{P}$ is .000 , therefore it can be concluded that there is a difference between the ages of SMEs in terms of their access to bank credit acquisition. Therefore H4 hypothesis will be accepted. Therefore H4 hypothesis will be accepted. In addition we have performed the Post Hock LSD test, to see in more detail the differences between the groups.

Table 9. Post Hock LSD Test Results

\begin{tabular}{llrllll}
\hline \multirow{2}{*}{ (I) The ages of SME } & Mean & \multirow{2}{*}{ Std. Error } & \multirow{2}{*}{ Sig. } & \multicolumn{2}{c}{ 95\% Confidence Interval } \\
\cline { 5 - 7 } & $2-5$ & -5178.2353 & 15971.7616 & .746 & -36662.900 & 26306.430 \\
$0-1$ & $6-10$ & -12389.5455 & 17807.4972 & .487 & -47492.942 & 22713.851 \\
& 11 years & $-104293.9286^{*}$ & 17016.4348 & .000 & -137837.927 & -70749.930 \\
& and more & 5178.2353 & 15971.7616 & .746 & -26306.430 & 36662.900 \\
$2-5$ & $0-1$ & -7211.3102 & 13967.9620 & .606 & -34745.944 & 20323.323 \\
\hline
\end{tabular}




\begin{tabular}{|c|c|c|c|c|c|c|}
\hline & $\begin{array}{l}11 \text { years } \\
\text { and more }\end{array}$ & $-99115.6933^{*}$ & 12944.3447 & .000 & -124632.500 & -73598.887 \\
\hline \multirow{3}{*}{$6-10$} & $0-1$ & 12389.5455 & 17807.4972 & .487 & -22713.851 & 47492.942 \\
\hline & $2-5$ & 7211.3102 & 13967.9620 & .606 & -20323.323 & 34745.944 \\
\hline & $\begin{array}{l}11 \text { years } \\
\text { and more }\end{array}$ & $-91904.3831^{*}$ & 15151.4305 & .000 & -121771.953 & -62036.813 \\
\hline \multirow{3}{*}{$\begin{array}{l}11 \text { years and } \\
\text { more }\end{array}$} & $0-1$ & $104293.9286^{*}$ & 17016.4348 & .000 & 70749.930 & 137837.927 \\
\hline & $2-5$ & $99115.6933^{*}$ & 12944.3447 & .000 & 73598.887 & 124632.500 \\
\hline & $6-10$ & $91904.3831^{*}$ & 15151.4305 & .000 & 62036.813 & 121771.953 \\
\hline
\end{tabular}

The table above shows the results of the Post Hock LSD Test. Based on the significance level Sig. Table for all age groups of SMEs, it can be stated that there is an important distinction to groups which are under the 0.05 level of significance. There are differences between the four age groups of SMEs. According to these results it can be concluded: the difference between them is Sig level. .000. So, the results we can see that longer-lived businesses have benefited most from access to bank loans. From the results it can be concluded that the older the SME was, the access to bank credit was higher. The result agrees with the findings of the authors Huynh \& Petrunia (2010) who found the positive correlation between growth and financial leverage of the enterprise which confirms the role and importance of using external resources for enterprise growth and development.

H5. There is a significant difference between the educational levels of SME founders, regarding obtaining bank loans, SME founders with a higher educational level have easier access to bank loans benefit.

Testing the fifth hypothesis is done by using One Way Anova and Welch- Brown-Forsythe test. In the following table we present descriptive frequency averages.

Table 10. Description of the mean scores for the level education of SME owners

\begin{tabular}{llrrrrr}
\hline & & \multirow{2}{*}{ Mean } & Std. & \multirow{2}{*}{ Std. Error } & \multicolumn{2}{c}{$95 \%$ Confidence Interval for Mean } \\
\cline { 6 - 7 } & & & Deviation & & Lower Bound & Upper Bound \\
\hline Primary & 4 & 1375.000 & 1376.8926 & 688.4463 & -815.943 & 3565.943 \\
Secondary & 65 & 19212.308 & 80132.4889 & 9939.2120 & -643.551 & 39068.166 \\
College & 93 & 10418.280 & 20736.4935 & 2150.2742 & 6147.649 & 14688.910 \\
Master & 51 & 109752.941 & 121365.6184 & 16994.5858 & 75618.311 & 143887.571 \\
Doctorate & 2 & 125000.000 & 176776.6953 & 125000.0000 & -1463275.592 & 1713275.592 \\
Total & 215 & 37537.674 & 86331.7359 & 5887.7755 & 25932.214 & 49143.135 \\
\hline
\end{tabular}

From the descriptive table we see the averages of the educational level groups of SME founders. Founders with a primary education have an average of 1,375.0, founders with a secondary education have an average of 19,212.30, founders with a college education have an average of 10,418.28, founders with a master's degree have an average of $109,752.94$, and founders with a doctoral degree have an average of $125,000.0$. Following is the table of One Way Anova.

Table 11. One Way Anova Results

\begin{tabular}{lrrrrr}
\hline & Sum of Squares & df & Mean Square & F & Sig. \\
\hline Between Groups & 376723721199.808 & 5 & 94180930299.952 & 16.235 & .000 \\
Within Groups & 1218254363637.400 & 210 & 5801211255.416 & & \\
Total & 1594978084837.210 & 215 & & & \\
\hline
\end{tabular}

The table shows the results of One Way ANOVAs that there is a difference between the educational levels of SME founders in terms of their approach to bank loan benefit. The value of $F$ is very large $F=16.235$, indicating that the analysis is of high importance. The table above shows that the value of P (Sig.) is less than 0.05 . Where in our case the value of $\mathrm{P}$ is .000 , so this indicates that there is a difference between the education levels of SME founders regarding their access to bank loan benefit. Therefore H5 hypothesis will be accepted. Following is the WelchBrown-Forsythe test. 
Table 12. Welch-Brown-Forsythe test results

\begin{tabular}{lrrrr}
\hline & Statistic $^{\mathrm{a}}$ & df1 & df2 & Sig. \\
\hline Welch & 11.856 & 4 & 7.637 & .002 \\
Brown-Forsythe & 8.029 & 4 & 2.290 & \\
\hline
\end{tabular}

The table above gives the results of the Welch-Brown-Forsythe test. Based on the level of significance Sig. 002 in the table for all groups by educational level of SME founders, it can be stated that there is a significant difference between the groups. According to these results it can be concluded: The difference between them is Sig level. .002, the graph shows that businesses with more advanced education owners have obtained more bank loans.

H6. There is no significant difference between the genders of SME founders regarding obtaining bank loans.

For the purpose of testing the sixth hypothesis, Independent-Samples T Test was used to investigate the difference between the two groups of averages. T-test determines whether the mean of one group is significantly different from the average of the other group.

Table 13. Description of the average results of SME owners by gender

\begin{tabular}{lllrrr}
\hline & & N & Mean & Std. Deviation & Std. Error Mean \\
\hline \multirow{2}{*}{ Loan amount } & Man & 182 & 31370.330 & 81617.4861 & 6049.8906 \\
& Women & 33 & 71551.515 & 103706.3918 & 18052.9656 \\
\hline
\end{tabular}

According to the results, the average of the 182 male participants is $31,370.33$, and the average of the 33 female participants is 71,551.51. There is a significant difference between groups based on averages and standard deviation.

Table 14. Independent-Samples T Test Results

\begin{tabular}{|c|c|c|c|c|c|c|c|c|}
\hline & & $\begin{array}{l}\text { Levene's } \\
\text { Equality o }\end{array}$ & $\begin{array}{r}\text { for } \\
\text { inces }\end{array}$ & t-test fo & Equality & of Means & & \\
\hline & & $\mathrm{F}$ & Sig. & $\mathrm{t}$ & df & $\begin{array}{l}\text { Sig. } \\
\text { (2-tailed) }\end{array}$ & $\begin{array}{l}\text { Mean } \\
\text { Difference }\end{array}$ & $\begin{array}{l}\text { Std. Error } \\
\text { Difference }\end{array}$ \\
\hline \multirow{2}{*}{$\begin{array}{l}\text { Loan } \\
\text { amount }\end{array}$} & $\begin{array}{l}\text { Equal } \\
\text { variances } \\
\text { assumed }\end{array}$ & 10.061 & .002 & -2.490 & 213 & .014 & -40181.1855 & 16139.3226 \\
\hline & $\begin{array}{l}\text { Equal } \\
\text { variances not } \\
\text { assumed }\end{array}$ & & & -2.110 & 39.503 & .041 & -40181.1855 & 19039.7149 \\
\hline
\end{tabular}

Even the Sig score $(p=.002)$ indicates that there is a significant difference between the averages of groups (value of Sig. Is less than 0.05 within the $95 \%$ confidence interval). In this way, it is concluded that the H6 hypothesis is rejected. According to the results of the analysis, it is clear that the gender of SME founders is also a determining factor in obtaining bank loans.

\section{Conclusion and Recommendation}

\subsection{Conclusion}

Based on the fact that small and medium-sized enterprises in the Republic of Kosovo are generators of economic development, it cannot be argued that they are currently facing insufficient financial resources, in particular startups. Challenges of SME financing in the Republic of Kosovo face difficulties in finding external funding sources also due to information asymmetry, which is a very common phenomenon between SMEs and financial institutions in Kosovo. The findings generated by the analytical section of the paper are summarized in the following conclusions:

- The first step in the growth and development of small and medium-sized enterprises and their easier access to external sources of financing is the necessity for the enterprise to have a business plan. 
Supporting this conclusion lies in the fact that small and medium-sized enterprises have insufficient internal resources.

- Enterprises with positive business activity enterprises have managed to significantly reduce the most challenges to access to bank loans, so the profit SME's is significant factor for the growth and development of the enterprise under planned projections. The results show that businesses with higher net profits have benefited higher credit amounts from banking institutions in the Republic of Kosovo.

- By activity, the findings show that manufacturing enterprises are not sufficiently supported by bank loans compared to commercial and service enterprises. The data show that manufacturing enterprises are still challenged by financial constraints. From the results it is concluded that the access of commercial and service enterprises to bank finance is easier compared to manufacturing enterprises.

- The age of the enterprise demonstrates this dualism: young enterprises are faced with various barriers (turnover, history, collateral, guarantors) to accessing bank loans, although older firms are much more likely to obtain financial support from banks. Here are the opposite poles, where in the first case banks are reluctant to back new start-ups because they do not meet the bank's requirements. The second case is that older enterprises have internal own funds and reduce the demand for external sources of financing. From the results of the analysis, it is clear that more experienced businesses have benefited more from access to bank loans.

- Also the level of education of the business owner is a significant factor in bank credit support. According to the results of the analysis, it is clear that businesses with educational background owners have managed to benefit more easily bank loans from financial institutions. It is worth noting that the proportion of owner education with primary education compared to doctorate is $1 / 11$.

- Gender owners of the enterprise compared with other variables shows that are significant in access to bank loans. According to the results of the analysis, it is clear that the gender of the SME founders is also a determining factor in obtaining bank loans. This implies that banks do not ignore the fact of what gender the owner is relying on other conditions, such as net rofit, turnover, collateral, credit history.

- Enterprises in Kosovo are heterogeneous categories specifying the various properties they possess such as age, gender, activity. In addition, the environment in which businesses operate is facing a number of problems (the rule of law, inefficiency of the judiciary and the lack of an economic court).

\subsection{Recommendation}

Based on the theoretical review of the relevant literature on SME financing, as well as the results generated from the questionnaire addressed to SMEs in Kosovo, concrete recommendations can be made for a group of actors: policymakers, financial institutions, businesses, regulatory authorities etc. The following are specific recommendations:

- Policy makers and public institutions including the Central Bank of Kosovo should encourage various forms of incentives to financial institutions, to increase their investments in favor of the domestic financial market.

- To create conditions for additional financial incentives to encourage further investments of the Diaspora and foreign investors in terms of raising financial funds as a potential for the development of small and medium-sized enterprises in the Republic of Kosovo.

- To accelerate the initiatives to establish a Commercial Court that would urgently resolve the large number of untreated cases that have been in their archives for years.

- Governmental institutions and commercial banks will be organized in terms of reducing the barriers faced by enterprises and create a favorable environment that would support the enterprise, especially micro and small enterprises.

- Small and medium-sized enterprises in the Republic of Kosovo should focus on human resource development by working closely with educational institutions. Education and training of new staff will create sufficient space to significantly increase the opportunity for enterprise development and

\section{References} entrepreneurship in the country.

Ardic, O. P., Mylenko, N., \& Saltane, V. (2011). Small and medium enterprises: a cross-country analysis with a new data set. World Bank Policy Research Working Paper No. 5538. The World Bank Group, Washington, DC. https://doi.org/10.1596/1813-9450-5538

Ayyagari, M., Beck, T., \& Demirgüç-Kunt, A. (2007). Small and medium enterprises across the globe. Small Business Economics, 29, 415-434. https://doi.org/10.1007/s11187-006-9002-5

Ayyagari, M., Demirgüç-Kunt, A., \& Maksimovic, V. (2008). How important are financing constraints? The role 
of finance in the business environment. The World Bank Economic Review, 22, 483-516. https://doi.org/10.1093/wber/lhn018

Beck, T., \& Demirgüç-Kunt, A. (2006). Small and medium-size enterprises: Access to finance as a growth constraint. Journal of Banking \& Finance, 30, 2931-2943. https://doi.org/10.1016/j.jbankfin.2006. 05.009

Beck, T., Demirgüç-Kunt, A., \& Honohan, P. (2009). Access to financial services: Measurement, impact, and policies. The World Bank Research Observer, 24, 119-145. http://doi.org/10.1093/wbro/lkn008

Beck, T., Demirgüç-Kunt, A., Laeven, L., \& Maksimovic, V. (2006). The determinants of financing obstacles. Journal of International Money and Finance, 25, 932-952. https://doi.org/10.1016/j.jimonfin. 2006.07.005

De la Torre, A., Ize, A. \& Schmukler, S. L. (2011). Financial development in Latin America and the Caribbean: the road ahead. World Bank Publications. https://doi.org/10.1596/978-0-8213-8847-1

Duygan-Bump, Levkov, \& Montoriol-Garriga, (2015). Financing constraints and unemployment: Evidence from the great recession. Journal of Monetary Economics, 75, 89-105. https://doi.org/10.1016/j.jmoneco.2014.12.011

Galindo, Arturo J., Fabio Schiantarelli, \& Andrew Weiss (2007). Does Financial Reform Improve the Allocation of Investment? Micro Evidence from Developing Countries. Journal of Development Economics, 83(2), 562587. https://doi.org/10.1016/j.jdeveco.2005.09.008

Nyugen T.A.H. (2017). Financing Constraints on SMES in Emerging Markets: Does Financial Literacy Matter? Review of Socio-Economic Perspectives, 2(2), 53-65. https://doi.org/10.19275/RSEP017

Harvie, Ch., Narjoko, D, \& Oum, S. (2013), Small and Medium Enterprises' Access to Finance: Evidence from Selected Asian Economics. ERIA-DP-23. Economic Research Institute for ASEAN and East Asia.

Hughes, A. (2009). Hunting the snark: Some reflections on the U.K. experience of support for the small business sector. Innovation: Management, Policy and Practice, 11(1), 114-126. https://doi.org/10.5172/impp.453.11.1.114

Shen, Shen, Xu, Bai, Shen, Y., Shen, M., Xu, Z., \& Bai, Y. (2009). Bank size and small- and medium-sized enterprise (SME) lending: Evidence from China. World Development, 37(4), 800-811. https://doi.org/10.1016/j.worlddev.2008.07.014

Tmava, Q., Peci. F., \& Luboteni, G. (2013). The Role of Banks in Small and Medium Enterprises Financing: A Case Study from Kosovo. International Journal of Economics and Finance, 5(12), 2013 https://doi.org/10.5539/ijef.v5n12p94

Vo, X. V. (2017). Determinants of capital structure in emerging markets: Evidence from Vietnam. Research in International Business and Finance, 40, 105-113. https://doi.org/10.1016/j.ribaf.2016.12.001

\section{Copyrights}

Copyright for this article is retained by the author(s), with first publication rights granted to the journal.

This is an open-access article distributed under the terms and conditions of the Creative Commons Attribution license (http://creativecommons.org/licenses/by/4.0/). 